\title{
Configurações
}

Revista de sociologia

$25 \mid 2020$

Debater o desenvolvimento: questões, dilemas e alternativas

\section{Um objeto complexo e fugidio? Uma introdução crítica ao desenvolvimento}

Fernando Bessa Ribeiro, Ivonaldo Leite e Joel Felizes

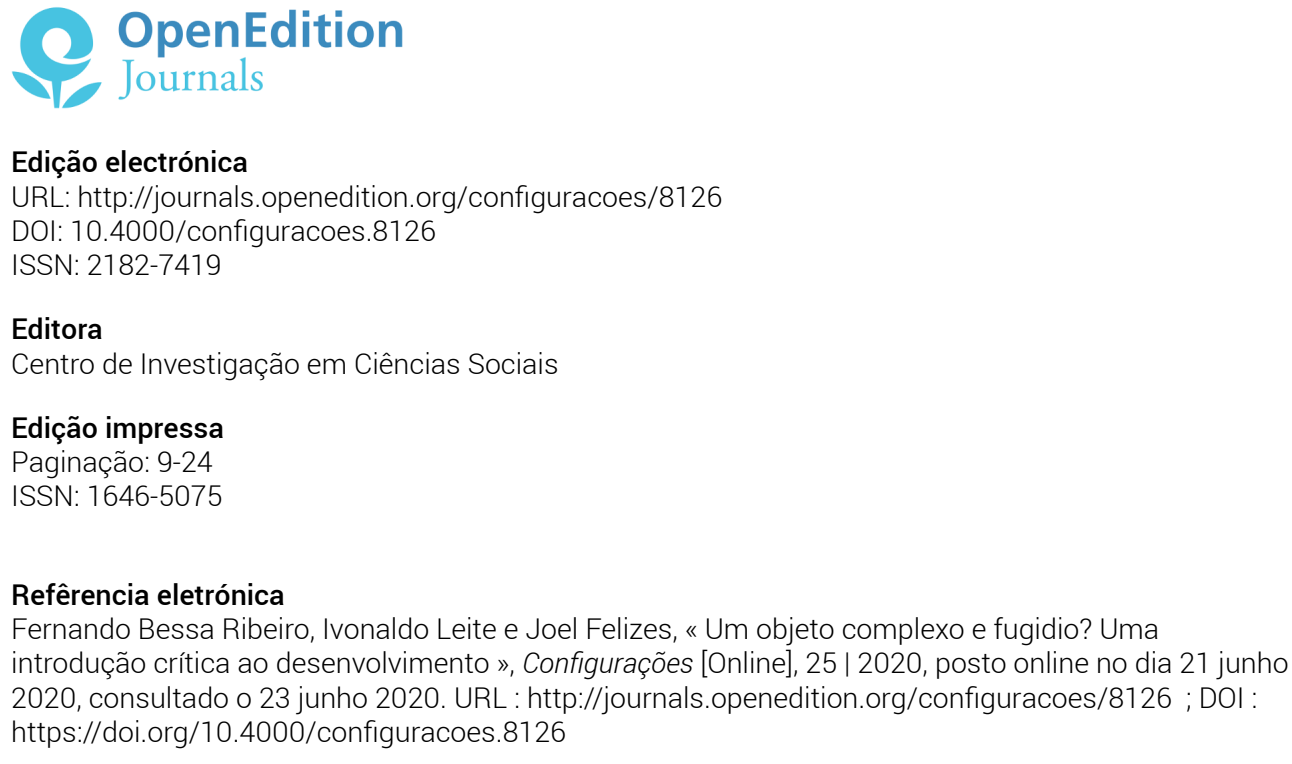


Ribeiro, Fernando Bessa; Leite, Ivonaldo; Felizes, Joel - Um objeto complexo e fugidio? Uma introdução crítica ao desenvolvimento. Configurações, vol. 25, 2020, pp. 9-24.

\title{
Um objeto complexo e fugidio? Uma introdução crítica ao desenvolvimento
}

\author{
FERNANDO BESSA RIBEIRO* \\ Departamento de Sociologia da Universidade do Minho \\ IVONALDO LEITE** \\ Departamento de Educação da Universidade Federal da Paraíba \\ JOEL FELIZES*** \\ Departamento de Sociologia da Universidade do Minho
}

Este texto foi escrito em plena crise sanitária global. Estamos, uma vez mais, confrontados com uma ameaça que se vai generalizando e ceifando vidas, desta vez por ação de um agente patogénico. Aparentemente nada de novo... a história está tingida de pandemias, algumas das quais mataram em número apreciavelmente superior ao que a atual parece capaz de fazer. Se circunscrevermos o nosso olhar ao continente europeu, a "gripe espanhola" de 1918 a 1920 matou em torno de 20 a 50 milhões de pessoas; a outra grande pandemia que permanece na memória coletiva, a peste negra do século XIV, terá provocado entre 75 e 200 milhões de mortos na Europa e na Ásia, dizimando seguramente mais de 1/3 da população então existente. Exceto para aqueles - e são muitos, como sempre ocorre nos momentos mais graves, em que a vida de cada um e dos que nos são próximos se joga de uma forma ainda mais aguda - que entendem a crise como portadora de um castigo contra a humanidade, ora imposto por alguma entidade divina, ora imposto pela natureza violada pela ação humana, "o vírus SARS Cov-2 não é um mensageiro" (Sousa Filho 2020).

A crise pandémica provocada pela disseminação acelerada do vírus, cujo primeiro surto identificado foi oficialmente comunicado pela China à Organização Mundial de Saúde (OMS) em 31 de dezembro de 2019, suscita questões cruciais

\footnotetext{
*E-mail: fbessa@ics.uminho.pt

**E-mail: ivonaldo.leite@gmail.com

***E-mail: jbfelizes@ics.uminho.pt
} 
para a nossa vida coletiva e o destino da sociedade humana.' Sem que elas tenham alguma vez deixado de estar presentes no debate teórico e político, os impactos económicos e sociais da Covid-19 e as respostas engendradas pelos governos colocam na ordem do dia algumas perguntas cruciais: será o capitalismo o modo final de organização da sociedade humana? A mercantilização de todas as coisas e a submissão da vida ao mercado, em nome de uma pretensa eficiência económica, é irreversível? Será que a mercantilização mais não pretende do que produzir as condições necessárias à obtenção de mais valias, constituindo uma escolha política e não um destino inelutável? Quais são os limites para o crescimento da economia e a exploração dos recursos naturais? Será a relação com a natureza e, em especial, com os outros seres vivos a mais adequada? Existirá alguma restrição para o tamanho da população humana, haverá um número que não deve ser ultrapassado? Será o progresso, nomeadamente o decorrente da ciência, sempre positivo ou comporta riscos e até catástrofes?

Apesar de hoje, por força das circunstâncias, serem mais urgentes, são questões velhas, há muito interpeladas. Embora o conceito de desenvolvimento seja uma ideia bem mais recente, na Grécia clássica, lembra-nos Taplin (1990: 145),

o "progresso" era visto em primeiro lugar como um avanço no conhecimento para o seu próprio bem, ao passo que, durante os últimos duzentos [anos], ele foi visto cada vez mais como a chave para vantagens materiais e comerciais. Por outras palavras, os Gregos queriam compreender a natureza como um fim em si mesma: a ciência moderna pretende compreender a natureza de modo a interferir nela e a controlá-la.

Instrumento fundamental ao desenvolvimento do capitalismo, o papel nele desempenhado pela ciência moderna e pela técnica foi genialmente percebido por Marx. Numa passagem luminosa de 0 Capital (vol. 1), o teórico alemão critica severamente os efeitos ambientais do capitalismo ao afirmar que

todo progresso da agricultura capitalista é um progresso na arte de saquear não só o trabalhador, mas também o solo, pois cada progresso alcançado no aumento da fertilidade do solo por certo período é ao mesmo tempo um progresso no esgotamento das fontes duradouras dessa fertilidade. [...] Por isso, a produção capitalista só desenvolve a técnica e a combinação do processo de produção social na medida em que solapa os mananciais de toda riqueza: a terra e o trabalhador (Marx 2014 [1867]: 571).

1 Conforme se pode ler no sítio de internet da OMS (2020), a sua delegação na China foi informada da existência de doentes com pneumonia de etiologia desconhecida residentes na cidade de Wuhan, província de Hubei. 
Alguns anos mais tarde, Engels (1978 [1873]: 183) sublinha que a realidade nos mostra a todo o tempo que a humanidade não se coloca acima da natureza, antes a ela pertence, não podendo as atividades económicas fazerem-se desligadas dela:

Os factos lembram-nos a cada passo que não reinamos sobre a natureza como conquistadores sobre um povo estrangeiro submetido, como alguém que estaria para além da natureza, mas que lhe pertencemos com a nossa carne, o nosso sangue, o nosso cérebro (Engels 1978 [1873]: 183).

A atual epidemia confirma-o. Não estamos fora da natureza, ela continua a condicionar as nossas vidas, a colocá-las até em causa. Num contexto marcado por agressões ambientais e danos irreversíveis nos ecossistemas e na diversidade das espécies, pelo avanço da colonização humana para zonas remotas do planeta, até hoje desabitadas ou escassamente povoadas (cf. Shah 2020: 13-14), parece que algo de novo surgiu nas últimas décadas. Desde o aparecimento do VIH que o mundo se confronta com uma sucessão de novas epidemias, a que se juntam surtos de outras já conhecidas: ${ }^{2}$ a SARS, a MERS, ${ }^{3}$ as gripes aviária (H5N1) e suína (H1N1) e as infeções provocadas pelos vírus Zika e Ébola. Seguindo os argumentos de Epstein (2007: 42) para o caso do VIH/sida, a rápida propagação da Covid 19 e seus efeitos têm de ser compreendidos considerando também as dinâmicas globalizadoras impulsionadas pelo capitalismo. Daqui decorre que "a Caixa de Pandora está aberta, e o nosso implacável sistema econômico está tornando tudo pior" (Davis 2020: 5). Isto é, o capitalismo não só produziu um tal impacto no planeta, ao ponto de ter provavelmente dado origem a uma nova era geológica, o antropoceno, como o caminho imposto pelo neoliberalismo nos últimos quarenta anos debilitou severamente os sistemas públicos, não só pela implementação deliberada e sistemática da escassez de recursos, como pela submissão de todas as estruturas do Estado às lógicas perversas e perigosamente temerárias do just in time, "otimização de recursos" e "eliminação da ociosidade". Como assinalam Lambert e Rimbert (2020: 26), "por toda a parte, uma palavra de ordem: reduzir custos. O hospital funcionará como uma fábrica automóvel, em modo 'produzir consoante a procura'". Assim, para bem entender estas articulações complexas entre a natureza e a humanidade, a síntese estimulante de Harvey (2020: 15) explica-nos que

\footnotetext{
2 Nossa (2001: 190) lembra que a infeção provocada pelo VIH colocou em causa a expetativa de muitos que consideravam, na década de 1970, a gripe como a derradeira doença epidémica a combater. Como referem Ribeiro e Sacramento (2012), o VIH apareceu no momento histórico em que os progressos nas tecnologias da vida prometiam um "mundo novo" à humanidade, destacando-se as terapias genéticas, cujos alicerces eram constituídos pela descoberta do ADN por Francis Crick e James Watson, em 1953, e a invenção, já nos anos de 1970, da clonagem de genes que possibilitou, em 1977, a primeira clonagem de um gene humano (Castells 1998: 83ss). À semelhança do que ocorreu com a sida, a Covid-19 confronta novamente a ciência e a sociedade com o espectro da contaminação infeciosa mortal globalizada que se presumia como muito improvável, graças ao avanço da medicina, da farmacologia e das tecnologias aplicadas ao campo da saúde humana.. 3 SARS é a sigla, em língua inglesa, para Severe A cute R espiratory Syndrome; MERS é a sigla, em língua inglesa, para $\mathrm{M}$ iddle E ast R espiratory Syndrome.
} 
há muito tempo eu tinha recusado a ideia de "natureza" como alheia e separada da cultura, economia e cotidiano. Eu tenho uma visão mais dialética e relacional da ligação metabólica com a natureza. O capital modifica as condições ambientais de sua própria reprodução, mas o faz num contexto de consequências não intencionais (como as mudanças climáticas) e contra as forças evolutivas autônomas e independentes que estão perpetuamente remodelando as condições ambientais. Deste ponto de vista, não existe um verdadeiro desastre natural. Os vírus mudam o tempo todo. Mas as circunstâncias nas quais uma mutação se torna uma ameaça à vida dependem das ações humanas.

Nada disto é indiferente ao desenvolvimento! Como escrevemos na chamada de artigos, o desenvolvimento é conceito multifacetado, complexo, polissémico, sujeito a sucessivas reformulações, adaptações e renovações. Tem um trajeto histórico feito de sucessos, fracassos e debates intensos, no qual a luta contra a doença e a morte prematura será, porventura, um dos objetivos e expressões mais consensuais. A abordagem crítica ao desenvolvimento exige que não seja visto apenas como um conceito técnico, mas também e sobretudo como um conceito social, político e moral (cf. Long 1977, Sen 1999, Silva e Cardoso 2005, Ribeiro 2017). Inseparável de outros conceitos-fortes da modernidade, como o do progresso, tal implica considerá-lo no debate sobre o desenvolvimento. Interpelando-o, será desejável quando, em seu nome, os múltiplos processos de desenvolvimento contribuíram para nos aproximar do colapso ambiental, sem que muitos dos problemas sociais tenham sido solucionados? Será ainda pertinente e viável, quando depois de tantas décadas e planos de desenvolvimento, as organizações internacionais continuam a visar objetivos tão simples mas urgentes e fundamentais como a erradicação da fome e da pobreza extrema? Enfim, de que falamos quando falamos de desenvolvimento?

O desenvolvimento não é interesse apenas da sociologia, é também da economia, da história, da geografia e da própria ciência política. Na verdade, o desenvolvimento, inseparável da ideia de progresso, constitui um objeto central no debate contemporâneo, podendo ser escrutinado mobilizando diferentes perspetivas teóricas e políticas. Procurando pensá-los de um modo dialético, no quadro do capitalismo, simultaneamente como avanço e catástrofe, seguindo as leituras de Jameson (1991) e de Löwy (2006) dos textos de Marx, desenvolvimento e progresso são conceitos e alicerces da ação política que necessitam de ser clarificados e discutidos, considerando nomeadamente as inovações tecnocientíficas que produziram a possibilidade bem real de destruição do planeta (v.g., guerra nuclear). ${ }^{4}$ Tendo como

4 É oportuno sublinhar que para Löwy (2006) "existe em Marx uma concepção dialética do progresso, que leva em conta o lado sinistro da modernidade capitalista. [...] Trata-se de pensar a história simultaneamente como progresso e como catástrofe, sem privilegiar um dos aspectos, pois a saída do processo histórico não está pré determinada. Um comentário de Frederic Jameson sobre o M anifesto Comunista capta bem este procedimento. 'Marx exige com força que façamos o impossível, isto é, pensemos este desenvolvimento (do 
"pano de fundo" uma demografia que vai levar a população humana para próximo dos dez mil milhões de indivíduos em meados do século, pelo que desenlace algum pode dispensar a sua convocação ao debate, este é nutrido também pelas propostas em torno do desenvolvimento sustentável, hoje incorporadas nos discursos e agendas políticas dos governos, bem como pelas propostas radicais do decrescimento e das alternativas pós desenvolvimentistas e pós-capitalistas. ${ }^{5}$

Não existindo consenso teórico e político sobre o que significa o desenvolvimento e sobre as políticas e práticas que o possam concretizar, os problemas sociais e ambientais que enfrentamos fazem dele objeto da maior relevância para avaliar o presente e escrutinar o futuro das sociedades humanas. Estas tarefas exigem o debate sobre a economia de mercado, suas lógicas, cadeias de produção e de distribuição, a globalização, o papel do Estado e a situação dos países afluentes e dos países pobres, entre tantas outras questões e dificuldades que inquietam o nosso quotidiano. Repetindo, todas elas têm de ser analisadas de modo dialético, mobilizando o melhor que a teoria nos oferece no campo dos estudos sobre o desenvolvimento, nomeadamente as do sistema mundial e da dependência, dando-se uma especial atenção às desigualdades sociais e seus efeitos e à relação entre a proteção da vida, num sentido amplo que não se circunscreve à espécie humana, e o funcionamento da economia.

Regressemos à crise sanitária que vivemos e da qual ainda não sabemos, no momento em que escrevemos este texto, quando acabará. Nem, muito menos, se estamos perante uma crise que será rapidamente superada, logo em 2021 ou 2022. Embora algumas coisas sejam certas - é uma crise sanitária global, contabilizando já mais de 300.000 mortos, com efeitos económicos devastadores, sobretudo nos países mais pobres e entre os trabalhadores pobres e precarizados de todo o mundo, incluindo nos países ocidentais -, a incerteza tinge o nosso horizonte. Apesar dos surtos epidémicos recentes, nomeadamente o H5N1 de 2005 e o H1N1 de 2009, os governos não asiáticos comportaram-se como se tudo não passaria de mais um sobressalto gripal. Podendo interpretar-se esta reação também como expressão de uma certa disposição mental, já presente noutras pandemias ocorridas entre os

capitalismo) ao mesmo tempo positiva e negativamente [pelo que] a civilização burguesa moderna aparece, em relação com as sociedades pré-capitalistas, ao mesmo tempo como um avanço e como uma regressão" (Löwy 2006: 261 e 263-264). A degradação não é apenas material, é também moral, como Löwy (2014: 32-34) justamente lembra ao citar diversos textos, como A miséria da filosofia e os M anuscritos económico-filosóficos. Neles Marx faz diversas considerações críticas sobre os efeitos devastadores do dinheiro e da mercantilização de todas as coisas - a quantificação venal da vida social -, a par da irracionalidade, que se exprime nas crises cíclicas de sobreprodução, e da dominação violenta e cruel de povos inteiros, primeiro pelo colonialismo, sob a forma de genocídio e escravatura, posteriormente pelo imperialismo.

5 Sendo certo que as teses malthusianas, nomeadamente no que se referem à ligação entre crescimento populacional e pobreza, não têm fundamento empírico, aliás já criticadas por Engels (2010 [1845]), a dimensão atual da população humana faz, a bem dizer, entrar Malthus pela "porta das traseiras". O problema não reside na escassez de recursos, nomeadamente alimentares, suficientes para satisfazer as necessidades da população humana atualmente existente, mas na pressão crescente que tal gera nos ecossistemas, num contexto manifestamente agravado pelas lógicas que guiam o capitalismo, aliás já objeto de análise no célebre relatório The L imits to G rowth (Meadows et al 1972). 
séculos XIV e XVIII - "quando surge o perigo de contágio começa-se por tentar não o ver" (Delumeau apud Lambert e Rimbert 2020: 26) -, havia principalmente que continuar com o business as usual, apesar do sofrimento que a pandemia pudesse provocar. Convocando uma interpretação genial acerca da economia de mercado por parte de Michel Foucault, em N ascimento da biopolítica, "a economia de mercado não subtrai algo do governo. Ao contrário, ela indica, ela constitui o indexador geral sob o qual se deve colocar a regra que vai definir todas as ações governamentais. É necessário governar para o mercado, em vez de governar por causa do mercado" (Foucault 2008 [1979]: 165). ${ }^{6}$ Os países europeus, os Estados Unidos da América, o Brasil, enfim, aos tropeções, os governos continuavam a governar para o mercado, quais comités de defesa dos negócios da burguesia, parafraseando Marxe Engels [1968 (1848)]. Quando o desastre se anunciava, certamente alguém lembrou que "os tempos de epidemias são sempre tempos de cólera" (Heers 1981: 91). Face à ameaça, os governos desligaram o capitalismo, congelaram as suas disposições intocáveis e trataram de, uma década depois da última grande crise, tudo fazer para o voltar a salvar. Como elenca Halimi (2020: 1), a Comissão Europeia desobriga os Estados-membros da aplicação das regras orçamentais, o governo norte americano entrega 1.200 dólares a cada um dos seus cidadãos, com a exceção dos ultrarricos. Žižek (2020: 13) pergunta: "Quanto das medidas comunistas que os que estão no poder são obrigados a aplicar agora permanecerão?"

Ensaiando a resposta, começamos por uma outra pergunta: porque haverão de ser diferentes as consequências da presente crise, se tomarmos como referência todas as anteriores que marcam o trajeto do capitalismo? Esta pressente-se como um evento devastador, atingindo setores importantes da economia, especialmente aqueles que dependem de diversas formas de interação social, como sejam o comércio em geral, e mais em particular, os diversos serviços pessoais, o turismo, a hotelaria e a restauração. Sendo, no seu todo, setores que concentram, em praticamente todo o mundo, parte significativa da mão de obra, o risco de estarmos no dealbar de uma catástrofe económica e social global é significativo, especialmente nos países periféricos. A isto acrescem os efeitos gerados pela contração da atividade económica em geral. Por exemplo, se a descida abrupta do preço de matérias primas, como o petróleo ou o gás natural, até pode parecer uma boa notícia para países não produtores como Portugal, ela naturalmente tem efeitos dramáticos, especialmente, insistimos, nas populações mais vulneráveis e dependentes do orçamento do Estado e das políticas públicas de proteção social de países como

6 Luiz Henrique Mandetta, o ex ministro da Saúde do governo brasileiro, demitido em abril de 2020 por Jair Bolsonaro devido a divergências insanáveis no caminho a tomar para conter a crise sanitária, fez numa entrevista à Folha de S. Paulo um comentário que, ainda que não intencional, converge objetivamente com o pensamento do filósofo francês. Implicitamente reconhecendo que no mercado se confrontam capitalistas e trabalhadores, no entender de Mandetta é a burguesia que reclama a reabertura da economia, fazendo uma analogia com a obra de Gilberto Freyre, Casa G rande e Senzala, afirmando que "só quem está gritando é a Casa Grande, que está vendo o dinheiro do engenho cair" (Folha de São Paulo 2020). 
Angola, Moçambique, Venezuela ou Brasil, apenas para citar alguns que nos são mais próximos.

Não obstante os apelos à coesão política e unidade de ação - "estamos juntos e juntos venceremos o vírus", proclama António Guterres, Secretário-geral da Organização das Nações Unidas (ONU 2020) -, aliás já desmanchados por Sousa Filho (2020), é necessário não perder de vista que a última grande crise do capitalismo foi aproveitada pela classe capitalista para consolidar o seu poder (Harvey 2011: 21 e 23). Por outras palavras, se as classes populares não forem capazes de se organizar e agir coletivamente, já sabemos a resposta à pergunta de Žižek... apesar de tudo, a incerteza subsiste. Se o capitalismo não desaparecerá por si próprio, a história não tem um caminho determinado. Em linha com o argumento de Hobsbawm (1994: 18), Wallerstein sublinha que "o futuro não está escrito em parte alguma, [...] ninguém sabe o que sairá das próximas décadas" (apud Vindt 1999: 153). Reconhecer a incerteza sobre os tempos que virão não implica admitir que tudo está igualmente em aberto. Nada sendo impossível, apesar de muito ser improvável, é pertinente admitir que a crise sanitária conduzirá a um capitalismo ainda mais brutal. Como escreve Žižek (2020: 13),

o resultado mais provável da epidemia é que um novo capitalismo bárbaro prevalecerá: muitos idosos e fracos serão sacrificados e deixados morrer, os trabalhadores terão de aceitar um padrão de vida muito mais baixo, o controlo digital das nossas vidas continuará a ser uma característica permanente, as distinções de classe tornar-se-ão (muito mais do que agora) uma questão de vida ou de morte...

Como já foi discutido por um de nós (Ribeiro 2017), os problemas económicos, ambientais e sociais são também políticos. Perante a dimensão global da pandemia e seus efeitos, a ação política deve também procurar aprofundar e mesmo desenhar novas formas multilaterais de cooperação global, algo que, com as variantes que se conhecem, tem vindo a ser proposto por muitas das teorizações sobre o desenvolvimento, designadamente as que inspiram a atuação das entidades que fazem parte da ONU. Todavia, a posição da atual administração norte-americana suscita justificadas dúvidas sobre as possibilidades de sucesso no campo da ação global. Por outro lado, não estando as alterações climáticas no "topo da agenda" das atuais prioridades, pois a urgência é defender a vida humana minimizando os efeitos da catástrofe, a prudência também nos ensina que não devemos suspender a luta no campo ambiental, pois é uma peça-chave na construção de economias e sociedades sustentáveis.

Ecossistemas, população, desigualdades sociais, tudo se mescla para se poder transformar em debates políticos e lutas sociais. Se assim o fizermos, politizaremos o que nos é apresentado como o destino inelutável, uma espécie de fatalismo sociopolítico que corrói o nosso sistema imunitário político, como diria Bourdieu (2001), 
desarmando nos e tornando nos incapazes de não só pensar fora do quadro da sociedade que existe, como imaginar outros destinos para humanidade. Que já estão a ser desenhados e concretizados por alguns de nós... se Latour (2017) estiver certo, quando afirma que as elites desistiram de governar o mundo, pretendendo antes proteger-se do caos ambiental, social e demográfico, tudo muda. Não é só o debate sobre o desenvolvimento que se coloca noutro patamar, é o próprio debate sobre o destino da sociedade humana que nos interpela implacavelmente, colocando no seu centro a pergunta de sempre: o que fazer com o capitalismo? Se as desigualdades são hoje obscenas, sublinha Dowbor (2014: 9), apoiado nos dados mobilizados por Piketty (2013), elas suscitam uma questão moral sobre o papel desempenhado pelas elites, em especial a mais abastada. Como referem Silva (2018) e Ribeiro (2018), na esteira de Ariño e Romero (2016) esta gente endinheirada é formada por ultrarricos tendo como principais fontes de riqueza as aplicações financeiras, as patentes e as obras públicas, em especial nos países emergentes. De certo modo constituem-se como um grupo à parte, uma "plutonomia" que se des $\neg$ prendeu dos outros segmentos da burguesia e da própria sociedade a que pertencem como nacionais e/ ou onde vivem. Sendo expressão de um processo, acentuam Ariño e Romero (2016), envolvendo dimensões económico-financeira, política, cultural, moral e residencial, esta secessão é levada muito a sério por esta camada social, traduzindo-se inclusivamente na imaginação de soluções exteriores ao próprio planeta. A construção de "capacidade de fuga", como a designa Rushkoff (2018), tem por objetivo sobreviver às alterações climáticas, às migrações e às pandemias globais, se necessário no espaço ou noutro planeta. Se é conhecida a ambição de Elon Musk em colonizar Marte, outros ultrarricos, certamente mais pragmáticos, limitam-se a olhar para a Nova Zelândia como o seu refúgio terrestre.?

Este número temático abre com um artigo de Viriato Soromenho-Marques sobre Henry David Thoreau. Descendente de imigrantes franceses, este autor norte-americano teve uma vida breve, morrendo de tuberculose aos 44 anos, em 1862. Não obstante, teve tempo de nos deixar uma obra valiosa, nomeadamente no domínio do ensaio político, onde se destaca $A$ desobediência civil, uma referência ainda hoje para pensar o libertarianismo e até o anarquismo. Mas é W alden; or, life in the woods que ocupa o centro da reflexão de Soromenho-Marques. ${ }^{8}$ Livro publicado em 1854, o título faz referência ao lago Walden, no Massachusetts, onde Thoreau viveu um par de anos numa cabana de madeira, desprendido dos bens materiais e das práticas de consumo que começavam a despontar na costa leste dos Estados Unidos da América, por força da primeira vaga de industrialização em curso nesse país. Como sublinha Soromenho-Marques, Thoreau tinha

7 Segundo a agência de notícias da Blomberg, alguns ultrarricos norte-americanos evitaram a pandemia da Covid 19 refugiando-se em abrigos subterrâneos que possuem na Nova Zelândia. Cf, entre muitos outros sítios de notícias, Bloomberg (2018 e 2020), El Pais (2017), New York Times (2017).

8 A obra está acessível em língua portuguesa. Entre outras edições, menciona-se Henry David Thoreau (2009), Walden ou A Vida nos Bosques. Lisboa, Antígona. 
uma consciência sensível das transformações que o mundo estava a viver, com a revolução industrial a deslocar camponeses para cidades poluídas, exigindo-lhes mais tarefas em menos tempo, enfim, iniciando uma aceleração do tempo social do qual jamais nos livramos. ${ }^{9} \mathrm{~W}$ alden ou a vida nos bosques exprime a procura de Thoreau dos caminhos para uma existência onde o "ser" predomine sobre o "ter", recusando muito do que é proporcionado pela sociedade moderna. SoromenhoMarques destaca as críticas que o autor faz ao trabalho na sua América contemporânea, aproximando-se de algumas das críticas que ao mesmo tempo, do outro lado do Atlântico, Marx estava a fazer, mobilizando o conceito de alienação. Se o teórico alemão escreve que no capitalismo a alienação advém da relação do trabalhador com o trabalho, no qual este não se afirma no trabalho, pelo contrário, nega-se e sente-se infeliz, o que nos diz Thoreau, citado por Soromenho-Marques, não é muito diferente: 10 "o trabalhador não tem discernimento para uma verdadeira integridade dia após dia; ele não pode dar-se ao luxo de sustentar as relações mais humanas com os homens; o seu trabalho seria depreciado no mercado. Ele não tem tempo para ser nada além de uma máquina". Daqui não decorre que Thoreau tenha sido um adepto da revolução socialista, pretendendo antes que a emancipação social, sugere Soromenho-Marques, se fizesse através da ação individual, tendo em vista construir um outro modo de viver. Para isso propõe um desprendimento em relação aos bens materiais e ao consumo, rejeitando o supérfluo, o que não é necessário a uma vida simples e autónoma. Para Soromenho Marques esta posição moral valorizando o individualismo não se opõe à defesa de princípios de justiça fundados na paz e na não discriminação, sendo legítimo que o indivíduo se recuse a pagar impostos, se eles se destinam a fins injustos, como fazer a guerra ou proteger a propriedade esclavagista, tal como os analisou em $A$ desobediência civil.

Sendo relevante o legado de Thoreau para o desenvolvimento das causas ambientais e da agenda da sustentabilidade, tendo influenciado figuras que no século XX se notabilizariam no campo do pensamento ecológico, SoromenhoMarques interpreta o legado de Thoreau também à luz do conceito de "Art of Living" de John Stuart Mill, presente nomeadamente em Princípios de economia política de 1848. No entender do filósofo e economista inglês, lembra Soromenho Marques, o progresso de todos os tipos de cultura e de avanços morais e sociais não conflituam com o estado estacionário da economia e da população. Se os argumentos de Stuart Mill (1951 [1848]) nos remetem para aspetos centrais do debate

9 Fazendo referência a esta vida acelerada, na carta encíclica "sobre o cuidado da casa comum", Francisco (2017) utiliza a expressão rapidáccion para dar a devida conta dos efeitos desastrosos que a aceleração das atividades humanas tem nos indivíduos e nos ecossistemas.

10 Dando a palavra a Marx, "o trabalhador, portanto, só se sente à vontade no seu tempo de folga, enquanto no trabalho se sente contrafeito. O seu trabalho não é voluntário, mas imposto, é trabalho forçado. Ele não é a satisfação duma necessidade, mas apenas um meio para satisfazer outras necessidades. O seu carácter alienado evidencia-se claramente no facto de, desde que não haja coacção física ou de qualquer outro tipo, ele ser evitado como uma praga" (Marx 1971 [1844]: 33-34). 
contemporâneo em torno do decrescimento, Viriato Soromenho Marques encerra o seu artigo sublinhando a atualidade do pensamento de Henry David Thoreau para a sustentabilidade ambiental e humana, fundada no apelo à responsabilidade individual, na qual o saber cuidar de si se assume como condição fundamental para cuidar da natureza, procedendo nomeadamente a um uso moderado dos recursos por ela disponibilizados.

João Carlos Graça apresenta-nos um artigo acerca do pensamento sobre o desenvolvimento e o modo como este foi sendo concretizado nas diferentes geografias, evidenciando as disputas entre Estados e as dinâmicas políticas e económicas que as marcam nos últimos 250 anos. Revelando um conhecimento minucioso de autores clássicos, como Karl Marx, Thomas Malthus e Adam Smith, sem descurar os mais recentes, como Immanuel Wallerstein, Kenneth Pomeranz e Jared Diamond, entre outros, os seus argumentos podem definir-se como não canónicos, considerando as tendências no campo dos estudos críticos sobre o desenvolvimento onde o autor se inscreve. Embora sublinhe que o desenvolvimento, como conceito, tem um certo viés eurocêntrico, e conhecendo bem os debates em torno do decrescimento e dos limites materiais do planeta, o autor assume uma posição crítica dentro da crítica, recusando as alternativas pós-desenvolvimentistas, em regra ancoradas em propostas que rejeitam o crescimento económico perpétuo. Trata-se de uma posição arriscada, pois a ideia de crescimento infinito está em contradição com o carácter finito do planeta, como muitos têm alertado - cf., entre outros, Latouche (2009) e Ribeiro (2017) -, aliás em linha com o sugerido por Stuart Mill (1951 [1848]) há mais de 150 anos. Neste sentido, é incontornável que o capital, analisado pelo autor, convocando nomeadamente Marx, enfrenta um constrangimento severo, a bem dizer, um limite insuperável, o da erosão progressiva dos recursos naturais - que O'Connor (1991) definiu brilhantemente como a segunda contradição fundamental do capitalismo - aliás antevista pelo teórico alemão, quando a refere implicitamente na luminosa passagem de 0 capital acima mencionada.

Prosseguindo com o confronto crítico dentro da crítica, as propostas decrescentistas não exigem a total liquidação do crescimento mas sim a adoção de políticas que, não o tendo como objetivo, o apliquem de modo variável, em função dos países e das classes sociais. De qualquer modo, não só o crescimento está em abrandamento - confira-se, por exemplo, as estimativas de Piketty (2013) para o presente século -, como combater os seus fundamentos - "a lógica íntima do capital", como justamente designa João Carlos Graça - é essencial para inverter e não apenas travar a "locomotiva" da história que nos leva para o abismo da catástrofe ambiental, convocando os argumentos de Löwy (2013). Muito mais há a dizer deste artigo, nomeadamente quando nos confronta com o papel decisivo do Estado nação no desenvolvimento, lembrando com aguda pertinência que é nele que a democracia se exprime. Deste modo, João Carlos Graça coloca-se em ostensivo confronto com 
os liberais e sociais democratas cosmopolitas que apressadamente prescreveram a morte do Estado-nação, recusando estes admitir que o nacionalismo, incluindo no plano económico e político no qual se opera o desenvolvimento, continua a desempenhar um papel-chave na melhoria das condições materiais dos povos e das nações, nomeadamente periféricos.

Pedro Rapozo e Manuel Carlos Silva desenvolvem uma ampla e consistente abordagem sobre as cartografias dos conflitos socioambientais na tríplice fronteira Brasil, Colômbia e Peru. Os autores põem em realce uma caracterização da violência e dos conflitos socio-ambientais relacionados com as diferentes formas de apropriação da natureza em terras tradicionalmente ocupadas pelos povos indígenas e não indígenas de comunidades agro extrativistas na microrregião do Alto Solimões, pertencente ao estado brasileiro do Amazonas, e que abrange a referida tripla fronteira. Não é uma empreitada fácil levar a cabo análises sobre as questões amazónicas com a consistência que os autores demonstram. Com 5,2 milhões de $\mathrm{km}^{2}$, a Amazónia corresponde a quase $60 \%$ do território brasileiro. A faixa de fronteira, com oito países, estende-se por mais de 10 mil quilómetros, em áreas pouco povoadas e de difícil acesso. Toda essa imensa extensão de terras baixas é cortada por rios, canais, lagos e lagunas que drenam a cordilheira dos Andes, o Planalto Central brasileiro e o maciço das Guianas e entregam aos oceanos $20 \%$ de toda a água doce que eles recebem (Benjamin, 2019). São 25 mil quilómetros de rios navegáveis, a mais extensa bacia hidrográfica do planeta. Trata-se de uma espécie de laboratório natural onde ocorrem processos biogeoquímicos complexos. A floresta e suas águas abrigam a maior biodiversidade do planeta, distribuída em plantas, mamíferos, aves, peixes, anfíbios, insetos e microrganismos, cuja maior parte ainda não é sequer conhecida. A flora contém cerca de trinta mil espécies.

Por essas poucas informações, é possível ter noção das questões socio-ambientais que a Amazónia abriga. É nessa esfera grandiosa e de aguda complexidade que Pedro Rapozo e Manuel Carlos Silva desenvolvem o seu percurso. Apetrecham-se de instrumentos de análise adequados e tratam dos conflitos socio-ambientais em conexão com os interesses de classe e a violência estatal, ocupam-se das manifestações de violência na tríplice fronteira amazónica, abordando nomeadamente a violação de direitos e as formas de existir. Pela pertinência e consistência do artigo, onde eventualmente o texto poderia ter agregado outros contributos seria em relação à economia da diversidade e a busca de equacionar os conflitos socio ambientais amazónicas em seu âmbito.

Continuando pela imensa Amazónia, Antônio Carlos Witkoski, Marília Gabriela Rezende e Therezinha de Jesus Fraxe convidam-nos a um percurso no universo de uma perspetiva que se tem acentuado bastante na América Latina nos últimos tempos: o "bem viver", ou buen vivir, conforme a sua expressão original oriunda dos países de língua espanhola. Os autores têm um propósito claro, evidenciado no título do artigo: "Notas sobre cooperativismo, gestão rural e bem viver na 
Amazónia: estratégias de resistência ao capitalismo". Ou seja, conectam o cooperativismo ao "bem viver" numa região-chave para o Brasil (e para o mundo), assumindo estes como elementos constituintes de contra-hegemonia ao capitalismo, tendo por bases práticas da economia solidária e da sociabilidade das populações amazónicas. Trata-se de uma abordagem promissora que os autores não esgotaram totalmente no artigo, nomeadamente no que diz respeito ao escrutínio do próprio conceito de "bem viver", assim como no que se refere à exploração da base empírica que inspira o trabalho. Implicitamente, o texto procura uma conciliação conceitual desafiante, ao assumir uma perspetiva de contra hegemonia ao capitalismo e, ao mesmo tempo, realçar dimensões que são bases da sua reprodução. Não é indiferente a esse enfoque ambivalente a noção de "desenvolvimento como liberdade", de Amartya Sen, referido pelos autores.

O artigo de Zênia Silva em torno dos temas da segurança e soberania alimentar e do combate à fome no Brasil é exemplar da relevância das abordagens do desenvolvimento que se focam na satisfação de necessidades básicas das populações dos diversos países. O texto destaca-se pela forma como descreve, por um lado, o percurso histórico da perceção do problema e, por outro, as iniciativas políticas, a nível global e também do Brasil, de combate à fome e de promoção da segurança alimentar e da nutrição. A este propósito, não deixa de ser paradoxal o facto de, num mundo que dispõe de recursos mais do que suficientes para prover bens e serviços básicos a toda a população, os problemas da pobreza extrema e da má nutrição tardarem em ser solucionados. A principal razão para a persistência deste problema é, tal como a autora refere, estrutural e prende-se com as "relações sociais da exploração capitalista e de dominação económica e política".

É certo que a generalidade dos países enfrenta, em graus diversos, ameaças à sua segurança e soberania alimentar, especialmente em cenários marcados pela existência de conflitos armados prolongados, mas também devido a fenómenos climáticos extremos, exponencialmente agravados pelos efeitos do aquecimento global. Zênia Silva alerta para a necessidade de, no Brasil, se promover um efetivo "compromisso político e social", o que não tem vindo a suceder nos últimos anos, pois o governo federal brasileiro, desde 2016, tem vindo a extinguir parte dos instrumentos da ação política que visava garantir a segurança alimentar e nutricional, o que põe em risco o cumprimento destes objetivos.

Por seu lado, no artigo "Reprodução capitalista e resistências indígenas: estudo comparativo entre Brasil e México", Clayton Rodrigues e Cleildes Santana partem de um enfoque histórico-sociológico para tratar de formas de resistência e guerras coloniais, tendo como centro das suas análises a população indígena. Isto é feito pretendendo-se colocar em evidência o que significou, para as populações nativas, o modo de desenvolvimento baseado no colonialismo. Os autores apresentam um panorama que conecta a expansão colonial dos séculos XIV e XV com as formas contemporâneas de dependência. Muito embora o colonialismo, 
no que concerne à investigação histórica, seja já um objeto vastamente analisado, principalmente na América Latina, sempre há de se ressaltar o valor de trabalhos que colocam esse tema sob escrutínio. Por outra parte, a forma de estruturação do texto, desenvolvido a partir de tópicos sintetizados, se tem a relevância de torná-lo objetivo, também o impede de ser mais extensivo em questões envolvendo populações nativas, colonialismo e dependência. O que pode funcionar, contudo, como estímulo à busca de outras análises sobre os temas enfocados.

Numa perspetiva mais local, focando o contexto atual e a evolução sociodemográfica e económica do concelho de Barcelos, no noroeste de Portugal, o artigo de António Cardoso apresenta-se como um exercício de demonstração de que, quando concentramos o olhar analítico numa região mais concreta, isso faz ressaltar o modo como o desenvolvimento tende a apresentar-se como bastante desigual, mesmo em países que, como no caso de Portugal, se podem considerar entre os que se apresentam com indicadores globalmente positivos. Por isso, se numa das mais conhecidas categorizações globais de países, no caso a do Programa das Nações para o Desenvolvimento, Portugal integra o grupo dos países com um nível de desenvolvimento humano "muito elevado", esta posição não é de facto a que experimenta uma parte significativa da população do país.

Percorrendo diferentes dimensões da vida social e económica da região onde se insere o concelho de Barcelos, com recurso abundante a indicadores estatísticos, o texto de António Cardoso vai percorrendo diferentes dimensões da vida social, onde não faltam, para lá dos indicadores socioeconómicos mais gerais, análises mais específicas de indicadores como os da área da saúde, dos equipamentos culturais ou da educação. São desse modo apontadas diversas fragilidades ao estado do desenvolvimento da região, cujo cenário, para o autor, tem de se interpretar tendo em conta "as respetivas condicionantes históricas sobretudo em termos económicos e político-culturais, agravadas por processos recentes de desagrarização e desindustrialização". Este retrato do concelho de Barcelos também aponta, no início do texto, para algumas das mais conhecidas abordagens teóricas do desenvolvimento económico e, na parte final, para possíveis soluções que permitam superar algumas das dificuldades verificadas.

Por fim, o artigo da autoria de Francisco Aguiar e de Xoán Lombardero apresenta-se como uma visão ampla e problematizadora de uma área científico-social que, tal como a sociologia, com quem partilha muitos pressupostos, tem sofrido evoluções significativas nas últimas décadas. De resto, o serviço social, se ainda é largamente tributário da sua orientação para a prática do diagnóstico e da intervenção social, é aqui retratado como uma disciplina dinâmica que reflete sobre o seu percurso histórico, reencontrando nos seus fundadores as preocupações com a justiça social, que desde cedo também são as preocupações com uma sustentabilidade socioambiental. 
Na sua análise, apoiada em inúmeras referências bibliográficas marcantes desta área científica, Aguiar e Lombardero procuram demonstrar que, nas últimas décadas, a abordagem teórica do serviço social oscila entre um paradigma largamente inspirado na teoria dos sistemas, e um outro, mais recente, que adota uma posição mais crítica. Nas palavras dos autores, "a teoria dos sistemas representa uma estratégia de adaptação enquanto a perspetiva eco-crítica seria uma estratégia de mudança social que não aceita a ordem estabelecida". O texto vai buscar à literatura alguns casos que marcaram a prática do serviço social, como o exemplo da atuação que procurou lidar com as consequências do furacão Katrina em 2005, especialmente em Nova Orleães, para dizer que ali houve possivelmente um foco excessivo dos assistentes sociais na intervenção pós-traumática de cariz psicoterapêutico, tendo faltado uma atuação mais ampla no quadro da própria organização da comunidade. Sublinha-se enfim que o "serviço social ambiental" é uma prática ainda pouco desenvolvida, defendendo por isso os autores que esta vertente se expanda no futuro.

A encerrar, uma breve referência para os derradeiros textos que compõem o presente número da revista C onfigurações. Um de nós, Ivonaldo Leite, escreve um extenso in memoriam de Theotônio dos Santos, uma figura maior das ciências sociais latino americanas. Com um percurso de vida sempre pela margem esquerda, este intelectual e professor brasileiro, exilado político duas vezes - em 1966, depois de dois anos na clandestinidade impostos pela ditadura militar brasileira, tendo partido para o Chile, depois no México, na sequência do golpe militar de Pinochet que assassinou Salvador Allende em 1973 -, é autor de uma obra académica e teórica inovadora e brilhante. É a Theotônio dos Santos que os estudos sobre o desenvolvimento devem um contributo maior para a elaboração da teoria da dependência que, em diálogo crítico e profícuo, com a teoria do sistema mundial e da economia-mundo capitalista, continua a oferecer um acervo teórico e político fundamental para compreendermos a história do capitalismo e os seus modos de desenvolvimento desigual. Já Antônio Carlos Witkoski, também autor de um dos artigos publicados neste número, elaborou um longo e interpelador comentário ao livro U ma sociologia do desenvolvimento.

\section{Referências bibliográficas}

ARIÑO, Antonio, \& Juan ROMERO (2016), L a secesión de los ricos, Barcelona, Galaxia Gutenberg. BENJAMIN, César (2019), Amazônia: cuidado, frágil, Boletim de C onjuntura Brasil, 8.

BLOOMBERG/Agência de notícias internacional (2018), The Super Rich of Silicon Valley Have a Doomsday Escape Plan (5 de setembro de 2018). Disponível em: www.bloomberg.com/features/2018-rich-new-zealand-doomsday-preppers/ (acedido em 25 de abril de 2020).

BLOOMBERG (2020), We Needed to Go': Rich Americans Activate Pandemic Escape Plans (19 de abril de 2020). Disponível em: https://tinyurl.com/ydxo9swm (acedido em 24 de abril de 2020). BOURDIEU, Pierre (2001), Contre-feux 2: pour un mouvement social européen, Paris, Raisons d'Agir. CASTELLS, Manuel (1998), L a société en réseaux: I'ère de l'information, Paris, Arthème Fayard. 
DAVIS, Mike (2020), "A crise do coronavírus é um monstro alimentado pelo capitalismo", In Mike Davis et al., C oronavírus e a luta de classes, Brasil, Terra sem Amos, 5-12.

DOWBOR, Ladislau (2014), "Entender a desigualdade: reflexões sobre o capital no século XXI", in Silvio Caccia Bava (org.), Thomas Piketty e o segredo dos ricos, (pp. 8-18), São Paulo: Veneta.

EL PAIS - Brasil (2017), "Elon Musk publica detalhes de seu plano para colonizar Marte. É realista?" (3 de julho de 2017). Disponível em: https://brasil.elpais.com/brasil/2017/06/23/ciencia/1498216022_307152.html (acedido em 24 de abril de 2020).

ENGELS, Friedrich (2010 [1845]), A situação da classe trabalhadora na Inglaterra, São Paulo, Boitempo.

ENGELS, Friedrich (1978 [1873]), D ialéctica da natureza, Lisboa, Presença.

EPSTEIN, Helen (2007), The invisible cure: Africa, the West and the fight against AID S, Londres, Penguin Books.

FOLHA DE S. PAULO (2020), "Mandetta escreve livro e diz que merece pito por abraços na despedida" (21 de abril de 2020). Disponível em: https://tinyurl.com/ydezhqua (acedido em 25 de abril de 2020)

FOUCAULT, Michel (2008 [1979]), N ascimento da biopolítica, São Paulo, Martins Fontes.

FRANCISCO (Papa) (2015), Carta encíclica L audato si': sobre o cuidado da casa comum, Vaticano, Libreria Editrice Vaticana.

HALIMI, Serge (2020), "O tempo é agora”, L e M onde D iplomatique (edição portuguesa), II Série, nº 162, 1 e 4.

HARVEY, David (2011), O enigma do capital - E as crises do capitalismo, Lisboa, Bizâncio.

HARVEY, David (2020), "Política anticapitalista em tempos de Covid-19", in Mike Davis et al., Coronavírus e a luta de classes, Brasil, Terra sem Amos, 13-23.

HEERS, Jacques (1981), O O cidente nos séculos XIV e XV: aspectos econômicos e sociais, São Paulo, Pioneira - Universidade de São Paulo.

HOBSBAWM, Eric (1994), A era dos extremos: história breve do século X X (1914-1991), Lisboa, Presença.

JAMESON, Fredric (1991), Postmodernism or, the cultural logic of late capitalismo, Londres, Verso.

LAMBERT, Renaud e Pierre RIMBERT (2020), "Até ao próximo fim do mundo...", L eM ondeD iplomatique (edição portuguesa), II Série, n 162, 26-28.

LATOUCHE, Serge (2009), Pequeno tratado do decrescimento sereno, São Paulo, WMF Martins Fontes. LATOUR, Bruno (2017), O ù atterrir? Comment s'orienter em politique, Paris, La Découverte.

LONG, Norman (1977), Introduction to the sociology of rural development, Wageningen, University of Wageningen.

LÖWY, Michael (2006), "A dialéctica marxista do progresso", In José Neves (org.), D a gaveta para fora: ensaios sobre marxistas, Porto, Afrontamento, 261-265.

LÖWY, Michael (2013), Crise ecológica, crise capitalista, crise de civilização: a alternativa ecossocialista, Cadernos C R H, v. 26, 67, 79-86.

LÖWY, Michael (2014), A jaula de aço: M ax W eber e o marxismo weberiano, São Paulo, Boitempo.

PIKETTY, Thomas (2013), L e capital au X X I e siècle, Paris, Seuil.

MARX, Karl (1971 [1844]), O s M anuscritos E conómico-Filosóficos, Porto, Brasília Editora.

MARX, Karl (2014 [1867]), O capital: crítica da economia politica (Livro primeiro - o processo de produção do capital), Rio de Janeiro, Civilização Brasileira.

MARX, Karl e Friedrich ENGELS [1968 (1848)], M anifesto do Partido Comunista, S. Paulo, Escriba.

MEADOWS, Donella, Dennis L. MEADOWS, Jørgen RANDERS e William W. BEHRENS III (1972), The limits to growth: a report for the Club of Rome's project on the predicament of mankind. Nova lorque, Universe Books.

MILL, John Stuart (1951 [1848]), Principios de economía política con algunas de sus aplicaciones a la filosofía social, Cidade do México, Fondo de Cultura Económica. 
NEW YORK TIMES (2017), "New Zealand Is 'the Future,' Peter Thiel Said in His Push for Citizenship" (1 de fevereiro de 2017). Disponível em: www.nytimes.com/2017/02/01/business/peter-thiel-new-zealand-citizenship.html (acedido em 25 de abril de 2020).

NOSSA, Paulo Nuno S. (2001), G eografia da saúde: o caso da sida, Lisboa, Celta.

O'CONNOR, James (1991), The second contradiction of capitalism: causes and consequences, CES/ C N S Pamphlet, 1.

OMS - Organização Mundial da Saúde (2020), "Pneumonia of unknown cause - China" (5 de janeiro de 2020. Disponível em: www.who.int/csr/don/05-january-2020-pneumonia-of-unkown-cause-china/en/ (acedido em 25 de abril de 2020).

ONU / UNRIC - Centro Regional de Informação das Nações Unidas para a Europa Ocidental (2020), "Covid-19: Juntos venceremos o vírus" (Artigo de opinião pelo secretário-geral das Nações Unidas, António Guterres). Disponível em: https://unric.org/pt/covid-19-juntos-venceremos-o-virus/ (acedido em 25 de abril de 2020).

RIBEIRO, Fernando Bessa (2017), U ma sociologia do desenvolvimento, Vila Nova de Famalicão, Húmus.

RIBEIRO, Fernando Bessa (2018), "Afinal a riqueza não flui de cima para baixo: capitalismo, desigualdades sociais e a ação do Estado", In Sílvia Gomes, Vera Duarte, Fernando Bessa Ribeiro, Luís Cunha, Ana Brandão e Ana Jorge, D esigualdades sociais e políticas públicas: homenagem ao professor M anuel Carlos Silva, Vila Nova de Famalicão, Húmus, 107-127.

RIBEIRO, Fernando Bessa e Octávio SACRAMENTO (2012), "Viver com a infeção: gestão da doença e quotidianos terapêuticos de doentes com VIH/sida no nordeste de Portugal", R evista A ngolana de Sociologia, n० 10, 111-130.

RUSHKOFF, Douglas (2018), "La supervivência de los más ricos y cómo traman abandonar o barco", In ctxt - R evista Contexto, no 180, 1 de agosto de 2018. Disponível em: http://ctxt.es/es/20180801/ Politica/21062/tecnologia-futuro-ricos-po bres-economia-Douglas-Rushkoff.htm (acedido em 20 de abril de 2020).

SEN, Amartía (1999), D evelopment as freedom, Oxford, Oxford University Press.

SHAH, Sonia (2020), "De onde vêm os coronavírus? Contra as pandemias, a ecologia", Le M onde D iplomatique (edição portuguesa), II Série, n 161, 13-14.

SILVA, Manuel Carlos (2018), "Pobreza, exclusão social e desigualdades: breve revisitação de conceitos e alguns dados a nível global e nacional", In Sílvia Gomes, Vera Duarte, Fernando Bessa Ribeiro, Luís Cunha, Ana Brandão e Ana Jorge, D esigualdades sociais e políticas públicas: homenagem ao professor M anuel Carlos Silva. Vila Nova de Famalicão, Húmus, 689-733.

SILVA, Manuel Carlos e António CARDOSO (2005), "O local face ao global: por uma revisitação crítica dos modelos de desenvolvimento", In Manuel Carlos Silva, Ana Paula Marques e Rosa Cabecinhas (orgs), O desenvolvimento e assimetrias socio-espaciais. Perspectivas teóricas e estudos de caso. Braga, Núcleo de Estudos em Sociologia da Universidade do Minho e Inovação à Leitura, 23-79.

SOUSA FILHO, Alípio (2020), "O vírus SARS-Cov2 não é um mensageiro" (8 de abril de 2020). In Blogue Convergência. Disponível em: https://convergencia-bloco.org/2020/04/08/o-virus-sars-cov-2nao-e-um-mensageiro-por-alipio-de-sousa-filho/ (acedido em 20 de abril de 2020).

TAPLIN, Oliver (1990), Fogo grego, Lisboa, RTC/Gradiva.

VINDT, Gérard (1999), 500 anos de capitalismo: A mundialização de Vasco da G ama a Bill G ates, Lisboa, Temas e Debates.

ŽIŽEK, Slavoj (2020), “Um golpe como o de 'Kill Bill' no capitalismo”, In Mike Davis et al., Coronavírus e a luta de classes, Brasil, Terra sem Amos, 43-47. 